\title{
Tag Dosing Unit
}

National Cancer Institute

\section{Source}

National Cancer Institute. Tag Dosing Unit. NCI Thesaurus. Code C82486.

A dosing unit equal to the amount of active ing redient(s) contained in a medicationinfused product that is attached to an animal. 